Aneta SYlWia BARANOWSKa

ORCID 0000-0001-5386-357X

Akademia im. Jakuba z Paradyża

w Gorzowie Wielkopolskim

\title{
BARIERY \\ INTEGRACJI UCZNIÓW CUDZOZIEMSKICH ZE ŚRODOWISKIEM SZKOLNYM
}

AвSTRAct. Baranowska Aneta Sylwia, Bariery integracji uczniów cudzoziemskich ze środowiskiem szkolnym [Barriers to Foreign Students' Integration into the School Environment]. Studia Edukacyjne nr 59, 2020, Poznań 2020, pp. 215-236. Adam Mickiewicz University Press. ISSN 1233-6688. DOI: 10.14746/ se.2020.59.14

Every year, more and more immigrants come to Poland. They settle in our country together with their school-age children. One of the tasks that immigrants and their children face is integration into Polish society. In the case of foreign children, it usually takes the form of integration into the school environment as they have the most frequent contact with the Poles at school. Integration into the school environment involves the inclusion of immigrant students in the social life of the school and simultaneously opening up the entire school community to their presence. Unfortunately, culturally different children encounter many obstacles, which significantly impedes success. These obstacles relate primarily to the lack of knowledge of the Polish language, emotional problems and a negative attitude towards their peers and their parents as well as to the teaching staff.

Key words: immigrants, foreign students, integration, school environment

Od zarania dziejów jedną ze znamiennych cech świata stanowią migracje zagraniczne, określane w literaturze przedmiotu jako „całokształt przesunięć prowadzący do zmiany zamieszkania osób, które przenoszą się z miejsca zamieszkania lub miejsca wyjazdu do miejsca przeznaczenia lub miejsca przyjazdu"1. Z najnowszego raportu ONZ, zatytułowanego The World Migration Report wynika, że w 2017 roku 258 milionów osób, czyli 3,4\% ludności świata, przebywało poza swoim krajem pochodzenia. To o 49\% więcej niż w 2000

${ }^{1}$ R. Bera, Aksjologiczny sens pracy a poczucie jakości życia młodych emigrantów polskich, Lublin 2008, s. 77. 
roku, co z kolei oznacza, że liczba migrantów międzynarodowych na przestrzeni ostatnich 17 lat wzrosła szybciej niż ludności świata².

Współczesne ruchy migracyjne są zjawiskiem złożonym, które można dzielić według różnych kryteriów, wyodrębniając wiele rodzajów migracjỉ Analizując mobilność jednostek, najczęściej wskazuje się na emigrację, czyli opuszczenie kraju pochodzenia przez jego obywateli oraz imigrację, czyli przyjazd do kraju obywateli innych państw. Światowe badania nad migracjami pozwoliły na wyróżnienie krajów o przewadze imigracji nad emigracją, czyli tak zwanych krajów imigracji netto, takich jak: Stany Zjednoczone czy Wielka Brytania oraz krajów o prymacie odpływu ludności nad jej napływem, czyli krajów emigracji netto, do których zalicza się między innymi Polska ${ }^{4}$.

\section{Imigranci w Polsce}

Do upadku komunizmu w 1989 roku polska polityka migracyjna miała charakter izolacjonistyczny, co oznacza, że nasz kraj był miejscem zamkniętym dla cudzoziemców ${ }^{5}$. Sytuacja ta uległa przeobrażeniu na początku lat 90. ubiegłego wieku. W tym czasie do Polski napływała większa liczba osób z zagranicy, w konsekwencji czego stopniowo zaczęła się ona przekształcać z kraju emigracyjnego, w kraj również przyjmujący imigrantów. W 1989 roku do Polski przybyło o 40\% więcej obcokrajowców niż w roku poprzednim $^{6}$. Wpływ na to miały dwa wydarzenia: rozpoczęcie zmiany systemowej i związanych $\mathrm{z}$ nią procesów $\mathrm{w}$ sferze liberalizacji ruchu granicznego oraz oddzielenie krajów należących niegdyś do bloku socjalistycznego od krajów zachodnich ${ }^{7}$. Należy jednak podkreślić, że zwiększony w latach 90 . ubiegłego wieku przyjazd cudzoziemców nie oznaczał, że Polska stała się krajem imigracyjnym. Narodowy Spis Powszechny w 2002 roku

pokazał niezwykle wysoką jednorodność etniczną mieszkańców Polski, wśród których jedynie 1,2\% zadeklarowało narodowość inną niż polską, a tylko 0,1\% nie posiadało polskiego obywatelstwa ${ }^{8}$.

${ }^{2}$ World Migration Report 2018, https://www.iom.int/wmr/world-migration-report-2018 [dostęp: 10/04/2019].

3 W. Gocalski, Migracje, [w:] Barwy i cienie migracji, red. W. Gocalski, Warszawa 2009, s. 19.

${ }^{4}$ A. Nowakowska, Wptyw migracji zarobkowej na jakość życia rodzinnego, [w:] Psychologia rodziny. Matżeństwo i rodzina wobec wspótczesnych wyzwań, red. T. Rostowska, Warszawa 2009, s. 101-102.

${ }^{5}$ K. Iglicka, Rola polityki migracyjnej Polski w ksztattowaniu migracji z Ukrainy z perspektywy teorii systemów, [w:] Migracje kobiet. Perspektywa wielowymiarowa, red. K. Slany, Kraków 2008, s. 103.

${ }^{6}$ A. Brzozowska, Wybrane grupy i charakterystyki imigracji do Polski, http://www.tea.org. pl/userfiles/file/Seminaria/wybrane_grupy_i_charakterystyki_imigracji_do_polski_-_tekst_ autorstwa_mgr_anity_brzozowskiej.pdf , s. 2 [dostęp: 28.11.2015].

${ }^{7}$ K. Iglicka, Rola polityki migracyjnej Polski, s. 104.

${ }^{8}$ S. Łodziński, A. Grzymała-Kazłowska, Koncepcje, badania i praktyki integracji imigrantów. Doświadczenia polskie w europejskim kontekście, Studia Migracyjne - Przegląd Polonijny, 2011, 2, s. 11. 
Również akcesja do Unii Europejskiej w 2004 roku oraz „kryzys migracyjny", wywołany masowym napływem uchodźców do Europy, nie zmienił radykalnie tej sytuacji - Polska wciąż jest raczej mało atrakcyjnym krajem dla migrantów poszukujących lepszych warunków własnej egzystencji. Należy jednak zaznaczyć, że postępująca integracja europejska, procesy globalizacyjne, zmiany demograficzne i wzrost ruchów migracyjnych w skali światowej powodują, że z roku na rok przybywa do niej coraz więcej obcokrajowców ${ }^{9}$. Jak wynika z danych zebranych przez Urząd ds. Cudzoziemców, w 2018 roku 372239 migrantów ze 183 krajów i 384 osoby bez obywatelstwa posiadały ważne dokumenty potwierdzające prawo ich pobytu na terytorium Rzeczypospolitej Polskiej. To o ponad 47 tysięcy osób więcej niż przed rokiem i o ponad 250 tysięcy więcej niż w 2011 roku $^{10}$.

Najwięcej dokumentów uprawniających do legalnego zamieszkania w Polsce mają obywatele Ukrainy $(48,1 \%)$. Prawie dziewięciokrotnie mniej zezwoleń udzielono Niemcom (5,7\%) oraz osobom pochodzącym z Białorusi $(5,4 \%)$. Obywatele tych trzech nacji stanowią ponad połowę wszystkich cudzoziemców, którzy posiadają dokumenty umożliwiające im zgodne z prawem przebywanie na terytorium Rzeczypospolitej Polskiej ${ }^{11}$. Warto nadmienić, że trend ten utrzymuje się od kilku lat i wiąże z pewnością z bliskością kulturową i geograficzną łączącą Polskę, Ukrainę, Niemcy i Białoruś.

Najwięcej zezwoleń na pobyt stały na terenie Polski, bo prawie połowę, mają obywatele Ukrainy $(49,6 \%)$. Białorusini znajdujący się na drugim miejscu posiadają ich prawie trzykrotnie mniej $(17,8 \%)$, a trzeci Rosjanie - prawie ośmiokrotnie mniej (6,3\%). Dane te potwierdzają informacje zawarte w Narodowym Powszechnym Spisie Ludności i Mieszkań z 2011 roku, z których wynika, że większość cudzoziemców przebywających w Polsce na stałe pochodzi z krajów byłego ZSRR ${ }^{12}$. W sumie dokumenty zezwalające na pobyt stały posiadają obywatele 152 krajów oraz bezpaństwowcy ${ }^{13}$.

Obywatele Ukrainy mają także 2/3 wszystkich zezwoleń na pobyt czasowy $(68,4 \%)$. Drugą narodowość pod względem liczby zezwoleń na ten rodzaj pobytu stanowią Hindusi (3,8\%), a trzecią Wietnamczycy (3,5\%). Dokumenty te posiadają osoby pochodzące ze 150 krajów ${ }^{14}$.

${ }^{9}$ A. Grzymała-Kozłowska, S. Łodziński S. (red.), Problemy integracji imigrantów. Koncepcje, badania, polityki, Warszawa 2008, s. 18.

10 Zestawienie liczbowe dotyczące postępowań prowadzonych wobec cudzoziemców w 2018 roku, Urząd ds. Cudzoziemców, Warszawa 2018, https://udsc.gov.pl/statystyki/raporty-okresowe/zestawienia-roczne/ [pobrano: 02.04.2019].

11 Tamże.

12 Narodowy Spis Powszechny Ludności i Mieszkań 2011, Główny Urząd Statystyczny, Warszawa 2011, s. 85.

${ }^{13}$ Zestawienie liczbowe dotyczace postępowań.

${ }^{14}$ Tamże. 
Z kolei, wśród osób posiadających prawo pobytu obywatela UE na terytorium RP dominują przede wszystkim Niemcy $(26,2 \%)$, a następnie Włosi $(10 \%)$ oraz Hiszpanie $(7,6 \%)$. Na podstawie tego prawa mieszkają w Polsce obywatele 31 europejskich państw ${ }^{15}$.

W 2018 roku na terytorium Polski przebywało 3351 osób, którym udzielono ochrony, czyli o 43 mniej niż przed rokiem. Pochodziły one z 55 krajów, wśród nich byli także bezpaństwowcy. Status uchodźcy mieli obywatele 44 krajów, a ochronę uzupełniającą przedstawiciele 38 nacji. Azyl posiadał tylko jeden migrant, narodowości białoruskiej. $Z$ danych Urzędu ds. Cudzoziemców wynika, że ochrona przyznawana jest przede wszystkim Rosjanom (50,3\%). Wśród nich znajduje się najwięcej uchodźców (29,3\%) i osób objętych ochroną uzupełniającą (64,7\%). Na drugim miejscu pod względem liczby uzyskanych form ochrony mieszczą się Ukraińcy (14,5\%), a na trzecim Syryjczycy $(9 \%)^{16}$.

Imigranci mieszkający w Polsce przybyli do niej głównie w celach zarobkowych, rodzinnych oraz edukacyjnych. Największa grupa cudzoziemców osiedliła się w województwie mazowieckim (114 tys.), małopolskim (36 tys.), dolnośląskim (31 tys.) oraz wielkopolskim (28 tys. ${ }^{17}$.

Cudzoziemcy przyjeżdżający do Polski mieszkają głównie w metropoliach. Znamienną cechą imigracji do Polski jest zatem jej charakter wyspowy. Oznacza to, że w dużych miastach obcokrajowcy stanowią widoczną grupę $\mathrm{w}$ populacjach studentów, pracowników, a także mieszkańców, natomiast $\mathrm{w}$ innych częściach Polski ich obecność jest niezauważalna i często związana ze specyficznymi czynnikami lokalnymi (np. istnieniem filii firmy zagranicznej zatrudniającej cudzoziemców $)^{18}$. Największą grupę imigrantów skupia aglomeracja warszawska. Powodów takiego stanu rzeczy jest kilka. W Warszawie jako stolicy Polski funkcjonują konsulaty krajów pochodzenia imigrantów, organizacje pozarządowe i instytucje międzynarodowe zajmujące się problematyką migracyjną. Warszawa jest także miejscem, które ma, spośród innych polskich miast, najlepsze połączenie lotnicze z miastami całego świata. Na atrakcyjność stolicy Polski wpływa również fakt, że stanowi ona największy w Polsce ośrodek akademicki oraz centrum biznesu. Zatem, w tym miejscu cudzoziemscy mają duże szanse na zdobycie należytego wykształcenia czy otrzymanie dobrze płatnej pracy $^{19}$.

15 Tamże.

16 Tamże.

17 https://udsc.gov.pl/podsumowanie-legalizacja-pobytu-w-2018-r/ [dostęp: 02.04.2019].

18 A. Górny i in., Raport z badania imigrantów w Polsce, Warszawa 2013, s. 9.

${ }^{19}$ P. Kaźmierkiewicz, Uwarunkowania integracji cudzoziemców w Polsce, [w:] Integracja cudzoziemców w Polsce. Wybrane aspekty, red. M. Bieniecki, P. Kaźmierkiewicz, B. Smoter, Warszawa 2006, s. 51. 
Przybywający nad Wisłę obcokrajowcy często osiedlają się w Polsce wraz ze swoimi dziećmi będącymi w wieku szkolnym. Jak wynika z najnowszych danych Głównego Urzędu Statystycznego, wśród imigrantów mieszkających w Polsce znajduje się 14665 osób, które nie ukończyły 18. roku życia (7 454 chłopców i 7211 dziewczynek). To o 4778 osób więcej niż w 2014 roku, co oznacza, że liczba dzieci cudzoziemskich także zintensyfikowała się na przestrzeni ostatnich kilku lat ${ }^{20}$.

\section{Integracja imigrantów - charakterystyka procesu}

Imigranci, w tym dzieci cudzoziemskie, po przybyciu do Polski stoją przed koniecznością odnalezienia się w nieznanym im otoczeniu. Proces ten w literaturze przedmiotu jest określany jako adaptacja i polega na „nabywaniu cech, właściwości i umiejętności, pozwalających sprawnie funkcjonować w danej, nowej sytuacji” ${ }^{21}$. W jego toku dokonuje się akulturacja, „odnosząca się do zmian, które następują jako wynik ciągłego bezpośredniego kontaktu pomiędzy jednostkami o różnym pochodzeniu kulturowym" ${ }^{22}$. Akulturacja obejmuje swym zasięgiem przemiany w systemach wartości, regułach życia, zasadach współżycia społecznego, normach moralnych, zachowaniach społecznych, często sięgając nawet do sfery wewnętrznej, a więc psychiki jednostki ${ }^{23}$. W procesie akulturacji duże znaczenie ma wybór odpowiedniej strategii akulturacyjnej ${ }^{24}$. John Berry wskazał cztery jej rodzaje: marginalizację, separację, asymilację oraz integrację $e^{25}$.

Pierwsza ma miejsce w sytuacji, kiedy imigranci zrywają kontakt ze społecznością rodzimą i nie wyrażają chęci do nawiązywania kontaktów z przedstawicielami grupy dominującej. Migranci doświadczają negatywnych emocji w kontakcie z kulturą pochodzenia i kulturą przyjmującą, izolują się od grupy własnej i większościowej.

Separacja występuje w przypadku, kiedy imigranci ograniczają kontakty do minimum z członkami społeczeństwa przyjmującego. Nie uczestniczą w kulturze przyjmującej, którą traktują jako mniej wartościową niż własna.

\footnotetext{
${ }^{20}$ Rocznik Statystyczny Rzeczpospolitej Polskiej, Warszawa 2017, s. 222.

${ }^{21} \mathrm{~K}$. Włodarczak, Proces adaptacji wspótczesnych emigrantów polskich do życia w Australii, Prace Migracyjne, 2005, 3, s. 3.

${ }_{22}$ M. Chutnik, Szok kulturowy. Przyczyny, konsekwencje, przeciwdziałanie, Kraków 2007, s. 69.

${ }^{23}$ E. Wysocka, Akulturacja, [w:] Encyklopedia pedagogiczna XXI wieku, red. T. Pilch, Warszawa 2003, s. 70.

${ }^{24}$ E. Olczak, Różnice kulturowe w funkcjonowaniu człowieka, [w:] Doradztwo zawodowe a wyzwania międzykulturowe, red. D. Cieślikowska, E. Kownacka, E. Olczak, A. Paszkowska-Rogacz, Warszawa 2006, s. 58.

${ }_{25} \mathrm{~J}$. Berry, Akulturacja: harmonijne życie pośród dwóch kultur, przekł. A. Mleczko, Rocznik Pedagogiczny, 2006, 29, s. 58.
} 
Źródłem satysfakcji są kontakty ze społeczeństwem rodzimym. W życiu codziennym posługują się językiem ojczystym.

Asymilacja z kolei polega na rezygnacji przez imigrantów z uczestnictwa w kulturze kraju pochodzenia i podtrzymaniu nowej kultury. Implikacją wyboru tej strategii jest ograniczanie kontaktów z rodakami. Cudzoziemcom może towarzyszyć niechęć wobec własnej kultury, na przykład do posługiwania się językiem rodzimym. Następuje także przejmowanie wzorów zachowań od społeczeństwa przyjmującego ${ }^{26}$.

Ostatnią z wymienionych strategii, uważaną przez znawców problematyki za najlepszą, jest integracja. Można ją rozumieć w dwojaki sposób: jako proces jednostronny, polegający wyłącznie na zaadaptowaniu się imigrantów do nowego środowiska lub jako dwustronny, w którym ma miejsce wzajemne oddziaływanie na siebie imigrantów i przedstawicieli grupy dominującej ${ }^{27}$. Zgodnie z drugim rozumieniem tego terminu, przyjętym w niniejszym artykule, imigranci muszą wyrazić chęć przystosowania się do odmiennie kulturowego społeczeństwa, a przedstawiciele grupy większościowej otworzyć się na cudzoziemców i nawiązywać z nimi kontakty oraz relacje ${ }^{28}$. Integracja wymaga zatem od imigrantów włączania się w życie społeczne obywateli kraju docelowego, a od ludności przyjmującej dobrej woli, polegającej na działaniach umożliwiających przybyszom integrację. Należy jednak zaznaczyć, że integracja uwzględnia poszanowanie prawa do zachowania własnej odrębności kulturowej przez cudzoziemców ze strony społeczeństwa przyjmującego, ponieważ zakłada, że utrzymanie własnej tożsamości kulturowej, na przykład poprzez spotkania z rodakami, ułatwi imigrantom adaptację do nowego otoczenia i radzenie sobie ze specyficznymi problemami towarzyszącymi zmianie miejsca zamieszkania ${ }^{29}$.

W przypadku dzieci cudzoziemskich integracja z polskim społeczeństwem przybiera na ogół formę integracji ze środowiskiem szkolnym, bowiem to właśnie w szkole, przez fakt spędzania w niej dużej ilości czasu, mają one najczęstszy kontakt z Polakami. Integracja ze środowiskiem szkolnym polega na włączaniu się uczniów-imigrantów w życie społeczne szkoły, przy jednoczesnym otwarciu się na ich obecność w placówce całej społeczności szkolnej, a więc: dyrekcji, nauczycieli, specjalistów, pozostałych pracowni-

26 Tamże, s. 58-59; M. Budyta-Budzyńska, Adaptacja, integracja, asymilacja - próba ujęcia teoretycznego, [w:] Integracja czy asymilacja? Polscy imigranci na Islandii, red. M. Budyta-Budzyńska, Warszawa 2011, s. 45-48.

27 A. Grzymała-Kozłowska, „Integracja” - próba rekonstrukcji pojęcia, [w:] Problemy integracji imigrantów. Koncepcje, badania, polityki, red. A. Grzymała-Kozłowska, S. Łodziński, Warszawa 2008, s. 35.

28 A. Grzymała-Kozłowska, S. Łodziński S. (red.), Problemy integracji imigrantów, s. 248.

29 A. Kicinger, Unia Europejska wobec zagadnienia integracji imigrantów, CEFMR Working Paper, 2005, 2, s. 3. 
ków, uczniów oraz opiekunów uczniów. Rezultatem tak rozumianej integracji powinno się stać lepsze funkcjonowanie poznawczo-społeczne dzieci z doświadczeniem migracyjnym oraz obustronne zadowolenie ze wzajemnych kontaktów.

\section{Edukacja dzieci cudzoziemskich w Polsce - aspekty prawne}

W świetle polskich przepisów prawnych, każde dziecko obcokrajowców, które nie ukończyło 18. roku życia ma prawo do bezpłatnej edukacji. Możliwość tę gwarantuje artykuł 70 Konstytucji Rzeczypospolitej Polskiej z 2 kwietnia 1997 r. oraz Ustawa z 14 grudnia 2016 r. Prawo oświatowe.

Osoby nieposiadające polskiego obywatelstwa mogą korzystać z nauki i opieki w publicznych przedszkolach lub publicznych innych formach wychowania przedszkolnego, a także $\mathrm{w}$ niepublicznych przedszkolach, oddziałach przedszkolnych $w$ niepublicznych szkołach podstawowych i niepublicznych innych formach wychowania przedszkolnego, a te podlegające obowiązkowi szkolnemu - z nauki i opieki w publicznych szkołach podstawowych, publicznych szkołach artystycznych oraz w publicznych placówkach, $\mathrm{w}$ tym placówkach artystycznych na warunkach dotyczących obywateli polskich $^{30}$.

Dzieci odmienne kulturowo, podlegające obowiązkowi szkolnemu lub obowiązkowi nauki mają prawo do dodatkowej, bezpłatnej nauki języka polskiego, w sytuacji gdy go nie znają lub porozumiewają się w nim w stopniu niewystarczającym. Zajęcia te realizowane są indywidualnie lub $w$ grupach w wymiarze pozwalającym na przyswojenie umiejętności władania językiem polskim na poziomie umożliwiającym udział $\mathrm{w}$ obowiązkowych zajęciach dydaktycznych, nie niższym niż 2 godziny lekcyjne tygodniowo ${ }^{31}$.

Uczniowie, którzy muszą uzupełnić różnice programowe z obowiązkowych przedmiotów mogą również uczestniczyć w dodatkowych zajęciach wyrównawczych w wymiarze 1 godziny lekcyjnej tygodniowo. Obowiązek organizowania powyższych form pomocy spoczywa na organie prowadzącym szkołę. Łączny wymiar godzin dodatkowych zajęć z języka polskiego i wyrównawczych nie może być wyższy niż 5 godzin lekcyjnych tygodniowo w odniesieniu do jednego ucznia ${ }^{32}$.

${ }^{30}$ Ustawa z 14 grudnia 2016 r. Prawo oświatowe, art. 165.

31 Rozporządzenie Ministra Edukacji Narodowej z 23 sierpnia 2017 r. w sprawie kształcenia osób niebędących obywatelami polskimi oraz osób będących obywatelami polskimi, które pobierały naukę w szkołach funkcjonujących w systemach oświaty innych państw, §17.

32 Tamże, §18-19. 
Dzieci cudzoziemskie mogą również w szkole uczyć się języka i kultury kraju ojczystego, jeżeli do udziału w tym kształceniu zostanie zgłoszonych co najmniej 7 uczniów. Zajęcia $\mathrm{z}$ tego zakresu może im zorganizować placówka dyplomatyczna lub konsularna kraju ich pochodzenia działająca na terytorium Rzeczypospolitej Polskiej albo stowarzyszenie kulturalno-oświatowe danej narodowości. Łączny wymiar godzin nauki języka i kultury kraju rodzimego nie może przekraczać 5 godzin lekcyjnych tygodniowo ${ }^{33}$.

Dzieci-imigranci mają także możliwość uzyskania wsparcia osoby władającej językiem kraju ich pochodzenia, zatrudnionej w charakterze pomocy nauczyciela przez dyrektora szkoły. Z propozycji tej, podobnie jak w przypadku zajęć wyrównawczych, mogą korzystać nie dłużej niż przez rok kalendarzowy ${ }^{34}$.

Od 1 września 2017 roku uczniowie cudzoziemcy, którzy nie posługują się językiem polskim lub czynią to w stopniu niewystarczającym do zdobywania wiedzy w grupie polskich rówieśników, czy też doświadczają innych trudności adaptacyjnych związanych z różnicami kulturowymi, mogą się uczyć w szkolnych oddziałach przygotowawczych, złożonych z nie więcej niż 15 dzieci, które przyjechały z zagranicy. Oddział ten tworzony jest przez organy prowadzące szkoły publiczne i niepubliczne wraz z początkiem września, ale w przypadku przyjęcia do placówki znacznej liczby uczniów, może on powstać również w trakcie roku szkolnego. Nauczanie w nim odbywa się według szkolnych programów nauczania, z dostosowaniem metod i form ich realizacji do indywidualnych potrzeb rozwojowych i edukacyjnych oraz możliwości psychofizycznych uczniów cudzoziemskich. Zajęcia dydaktyczne $\mathrm{w}$ oddziale przygotowawczym prowadzą nauczyciele poszczególnych przedmiotów, którzy mogą być wspomagani przez osobę władającą językiem kraju rodzimego ucznia. W ramach tygodniowego wymiaru godzin realizuje się w nim naukę języka polskiego, która odbywa się według programu nauczania opracowanego na podstawie ramowego programu kursów nauki języka polskiego dla cudzoziemców. Na zajęcia te przeznacza się minimum 3 godziny tygodniowo. Nauka w takim oddziale trwa do zakończenia zajęć edukacyjnych w roku szkolnym, w którym uczeń został do niego zakwalifikowany, ale może ulec skróceniu lub wydłużeniu przez radę pedagogiczną na wniosek uczących ucznia nauczycieli, pedagoga lub psychologa. Scharakteryzowanego oddziału przygotowawczego nie organizuje się w szkołach: artystycznych, specjalnych, sportowych, mistrzostwa sportowego oraz dla dorosłych ${ }^{35}$.

${ }^{33}$ Tamże, $\$ 20$.

${ }^{34}$ Ustawa z 14 grudnia 2016 r. Prawo oświatowe, art. 165, pkt. 8.

35 Tamże, art. 165, pkt. 11-14; Rozporządzenie Ministra Edukacji Narodowej z 23 sierpnia 2017 r. w sprawie kształcenia osób niebędących obywatelami polskimi, §16, pkt. 1-9. 
W praktyce dzieci cudzoziemskie, niezależnie od znajomości języka polskiego, uczestniczą w zajęciach szkolnych wraz z polskimi uczniami, mając przy tym możliwość korzystania z wymienionych powyżej form pomocy.

\section{Trudności w integracji uczniów cudzoziemskich ze środowiskiem szkolnym}

Uczniowie cudzoziemscy wraz $\mathrm{z}$ rozpoczęciem nauki w nowej szkole przeżywają wiele problemów, które znacząco utrudniają im integrację ze środowiskiem szkolnym. Jednym z nich jest brak umiejętności porozumiewania się w języku ojczystym kraju, do którego wyemigrowali. Sytuacja ta rodzi szereg negatywnych konsekwencji: dzieci te nie rozumieją treści przekazywanych $\mathrm{w}$ trakcie lekcji, potocznych wyrażeń czy młodzieżowego slangu; nie potrafią wyrażać swoich potrzeb, odpowiadać na pytania, nawiązać kontaktu z rówieśnikami i nauczycielami ${ }^{36}$. Niestety, w obliczu doświadczanych problemów nie zawsze uzyskują ze strony szkoły odpowiednią pomoc językową. Wiele placówek nie otrzymuje bowiem wystarczających funduszy na organizację kilku godzin lekcyjnych dodatkowych zajęć z języka polskiego. Zdarza się także, że w zajęciach tych biorą udział dzieci różniące się stopniem znajomości języka polskiego, co bardzo utrudnia nauczycielowi prowadzenie lekcji i dostosowanie materiału do potrzeb edukacyjnych wszystkich jej uczestników. Nie zawsze też zajęcia te realizują osoby właściwie do tego przygotowane. $Z$ reguły zostają one przydzielone nauczycielom języka polskiego, którzy nie mają wykształcenia w zakresie nauki języka polskiego jako obcego i jedynie adaptują program nauczania wykorzystywany w klasach standardowych do zajęć z uczniami cudzoziemskimi ${ }^{37}$. Warto również wspomnieć, że zajęcia te na ogół odbywają się po lekcjach obowiązkowych. Młodzi imigranci są więc często zmęczeni kilkugodzinnym pobytem w szkole i nie mają już większych chęci na przyswajanie nowego słownictwa czy zasad gramatyki. W efekcie, jak wynika z danych Ministerstwa Edukacji Narodowej, tylko $18 \%$ z nich regularnie korzysta z oferowanych im lekcji języka polskiego ${ }^{38}$. Są to bardzo niepokojące informacje, ponieważ to właśnie język stanowi „klucz do zrozumienia kultury, świata ludzkich znaczeń i wartości, ale też społecznej rzeczywisto-

${ }^{36}$ K. Białek, Międzykulturowość w szkole. Poradnik dla nauczycieli i specjalistów, Warszawa 2015, s. 13-14.

${ }^{37}$ K. Kubin, J. Świerszcz, Wyzwania dla szkoty różnorodnej. Wstępna analiza mechanizmów wykluczania dzieci i rodzin migranckich w strukturach szkoty w Polsce, [w:] Edukacja międzykulturowa w Polsce wobec nowych wyzwań, red. A. Paszko, Kraków 2011, s. 144.

38 A. Fihel, Koszt edukacji cudzoziemskich dzieci, Biuletyn Migracyjny, 2014, 49, s. 8. 
ści" ${ }^{39}$. Zatem, bez umiejętności porozumiewania się w jezyku polskim dzieci odmienne kulturowo nie są $\mathrm{w}$ stanie zintegrować się ze środowiskiem szkolnym.

Kolejną trudność w integracji uczniów cudzoziemskich w szkole stanowi nieznajomość zasad rządzących komunikacją niewerbalną i relacyjną w nowej kulturze ${ }^{40}$. Niewerbalne aspekty interakcji społecznych dotyczą sposobu wyrażania uczuć i emocji, przyjmowania właściwej postawy i utrzymywania odpowiedniej odległości od partnera interakcji, przeprowadzania rytuałów, takich jak: powitanie, mówienie o sobie, czy składanie lub odrzucanie ofert ${ }^{41}$. Pomimo istnienia sygnałów uniwersalnych, które można spotkać u wszystkich narodów i ras $^{42}$, znaczenie większości niewerbalnych komunikatów widocznych w zachowaniu ludności przyjmującej jest inne niż w kulturze pochodzenia imigrantów. To z kolei oznacza, że dzieci cudzoziemskie jako osoby wzrastające $\mathrm{w}$ innym środowisku kulturowym mogą mieć duży problem z prawidłową interpretacją mowy ciała członków grupy dominującej ${ }^{43}$.

Pisząc o trudnościach w skutecznym porozumiewaniu się uczniów-imigrantów ze społecznością szkolną, warto również wspomnieć o kontekście, polegającym na stopniowym wykorzystaniu symboli, znaków, przenośni, powiedzeń, mających pewne znaczenie dla określonej kultury. Wyróżniamy kultury niskokontekstowe (np. Niemcy, Skandynawia) oraz wysokokontekstowe (np. Daleki Wschód, kraje arabskie). Pierwsze komunikują się w sposób jasny, precyzyjny, bezpośredni, bez wykorzystania szerokiej gamy symboli, oczekują konkretnej instrukcji od mówiącej do nich osoby, nie zwracają większej uwagi na elementy pozawerbalne, wymagają uszczegółowienia źródła informacji. Kontekst nie jest potrzebny dla prawidłowego zrozumienia przekazu $^{44}$. Z kolei kultury wysokokontekstowe preferują komunikowanie niewerbalne; przyzwyczajone są do wtrąceń, przerywania w trakcie komunikowania; korzystają z rozwiniętych sieci informacyjnych i kontaktów; wyko-

${ }^{39}$ Sapir, za: E. Chromiec, Mniejszości narodowe i etniczne w Polsce - pytania i problemy okresu transformacji, [w:] Społeczeństwo wobec Innego. Kategoria Innego w naukach społecznych i życiu publicznym, red. L. Dziewięcka-Bokun, A. Śledzińska-Simon, Torun 2010, s. 223.

${ }^{40}$ M. Chutnik, Szok kulturowy, s. 29.

${ }^{41}$ Tamże, s. 43.

${ }^{42} \mathrm{~Np}$. ruch dłoni w kierunku nosa w sytuacji, gdy nie jesteśmy w stanie podjąć żadnej decyzji czy wyrażanie zakłopotania poprzez dotykanie włosów lub drapanie głowy; sześć podstawowych rodzajów mimiki odpowiadających następującym emocjom: szczęściu, zdziwieniu, strachowi, smutkowi, gniewowi oraz wstrętowi lub pogardzie (W. Sikorski, Różnice międzykulturowe w zachowaniach i komunikacji niewerbalnej, [w:] Wieloaspektowość komunikacji spotecznej w środowisku wielu kultur, red. K. Czerwiński, M. Fiedor, D. Wosik-Kawala, Toruń 2012, s. 35-37).

43 J. Bolten, Interkulturowa kompetencja, Poznań 2006, s. 38.

${ }_{44}$ M. Bartosik-Purgat, Otoczenie kulturowe w biznesie międzynarodowym, Warszawa 2006, s. 69; M. Szopski, Komunikowanie międzykulturowe, Warszawa 2005, s. 91. 
rzystują kontekst sytuacyjny i obyczajowy jako źródło informacji; koncentrują się na sugerowanych przez kontekst źródłach informacji ${ }^{45}$.

Problem w komunikacji osób pochodzących z różnych kultur mogą również stanowić wzory komunikowania się. W niektórych kulturach osoba mająca autorytet, na przykład osoba starsza jest tą, która inicjuje interakcję. Nie należy się do niej odzywać póki ona nie rozpocznie rozmowy. Ponieważ nauczyciel z reguły będzie postrzegany jako osoba obdarzona autorytetem, dzieci cudzoziemskie mogą oczekiwać, że to on będzie kierował przebiegiem rozmowy. Natomiast edukator może błędnie ocenić jego postawę, traktując ją na przykład jako przejaw niechęci do konwersacji ${ }^{46}$.

W obliczu braku wiedzy na temat zasad rządzących komunikacją werbalną i niewerbalną w nowym otoczeniu, uczniowie cudzoziemcy przejawiają postawy etnocentryczne, polegające na „interpretowaniu zachowań innych ludzi z perspektywy norm własnej kultury"47, co w konsekwencji prowadzi do wielu nieporozumień z rówieśnikami i nauczycielami oraz zmniejsza prawdopodobieństwo integracji ze środowiskiem szkolnym.

Na integrację dzieci-imigrantów w szkole ma również wpływ przeżywany przez nich „szok kulturowy”, określany inaczej jako stres akulturacyjny (ang. culture shock), szok językowy (language shock), szok związany z rolą (role shock), czy „zmęczenie kulturą” (culture fatigue) ${ }^{48}$. Jest nim

rezultat napotykanych $\mathrm{w}$ kulturze przyjmującej trudności, a jego istotą staje się doświadczanie nieprzyjemnych emocji, które kumulując się, owocują pogorszeniem ogólnego samopoczucia i satysfakcji z życia i co za tym idzie całości funkcjonowania człowieka ${ }^{49}$.

Stanowi on dynamiczny, aktywny proces radzenia sobie ze zmianą, negatywną reakcję na nową kulturę ${ }^{50}$. W literaturze przedmiotu wskazuje się na następujące szczegółowe jego symptomy, jak: znudzenie otoczeniem, ogólny niepokój i nieufność, ekstremalne reakcje na nieistotne sprawy, zmniejszony apetyt, frustracja, apatia, unikanie kontaktu z innymi ludźmi, zwłaszcza z osobami spoza swojego kręgu kulturowego, tęsknota za rodzinnym krajem, przeciążenie układu nerwowego i zmęczenie, nieustająca krytyka nowego

\footnotetext{
${ }^{45}$ M. Szopski, Komunikowanie międzykulturowe, s. 91.

${ }^{46}$ H. Grzymała-Moszczyńska, Uchodźcy jako wyzwanie dla polskiego systemu opieki zdrowotnej, [w:] Migranci na polskim rynku pracy. Rzeczywistość, problemy, wyzwania, red. Witold Klaus, Warszawa 2007, s. 14.

${ }^{47}$ E. Kownacka, Od szoku do adaptacji: psychologiczne konsekwencje wyjazdu za granice, [w:] Doradztwo zawodowe a wyzwania międzykulturowe, s. 46-47.

${ }^{48} \mathrm{~J}$. Grzymała-Moszczyńska, Psychologiczne aspekty powrotów z emigracji - przeglad teoretyczny, Studia Migracyjne - Przegląd Polonijny, 2014, 4, s. 53.

${ }^{49}$ E. Olczak, Różnice kulturowe w funkcjonowaniu człowieka, s. 42.

${ }^{50}$ M. Chutnik, Szok kulturowy, s. 89.
} 
otoczenia, brak chęci do poznania języka kraju przyjmującego i zwyczajów obchodzonych w nowej kulturze; chęć powrotu, duża identyfikacja z rodzimym krajem ${ }^{51}$.

Scharakteryzowany szok kulturowy związany jest z poczuciem obcości, jakie towarzyszy dzieciom odmiennym kulturowo w nowym miejscu zamieszkania. Obcość budzi otoczenie ludzkie; środowisko materialne: krajobraz, przedmioty codziennego użytku, pokarmy; warunki klimatyczne ${ }^{52}$, w szkole szczególnie zaś: inna aranżacja wnętrza placówki (np. podwójne ławki w klasie); funkcje podstawowych miejsc w szkole, takich jak: sklepik, sala, świetlica, biblioteka, stołówka, szatnie, sala gimnastyczna, pokój nauczycielski oraz oznaczenie ich w języku polskim; normy panujące w szkole, związane z: prywatnością i własnością (np. prywatne przybory szkolne, wieszaki w szatni oddzielnie dla każdej klasy), płcią (np. wspólne szatnie, oddzielne toalety i zajęcia z wychowania fizycznego), sferą nauczycielską i uczniowską (np. oddzielne toalety dla kadry pedagogicznej i dla uczniów) oraz harmonogramem dnia (np. czas nauki, czas odpoczynku, przerwa obiadowa, następujące po sobie lekcje z różnych przedmiotów $)^{53}$. Niestety, przechodzenie od stanu obcości do stanu swojskości, a więc pokonanie tak zwanego dystansu społecznego, jest długotrwałym i z reguły niełatwym procesem, wymagającym od dzieci-imigrantów wielu wysiłków ${ }^{54}$. To z kolei oznacza, że uczniom cudzoziemskim przez długi czas ich pobytu w Polsce towarzyszą negatywne emocje, które mogą zniechęcać do integracji ze środowiskiem szkolnym.

Warto również nadmienić, że dzieci te $\mathrm{w}$ obliczu doświadczanych problemów nie zawsze mogą liczyć na wsparcie ze strony swoich rodziców. Wynika to $\mathrm{z}$ tego, że ich opiekunowie jako dorośli imigranci również zmagają się z wieloma trudnościami adaptacyjnymi i wyzwaniami. Po przybyciu do Polski muszą zalegalizować swój pobyt, znaleźć pracę, nauczyć się języka polskiego. Wszystko to zabiera im sporo czasu, którego z reguły nie wystarcza na rozmowy z dziećmi na temat przeżywanych przez nich problemó $w^{55}$.

To, jak dużą trudnością okaże się komunikacja z Polakami oraz jak silnego szoku kulturowego doświadczy migrujący uczeń zależy od dystansu kulturowego, jaki dzieli kraj jego pochodzenia i Polskę. Pod jego pojęciem należy

${ }^{51}$ Tamże, s. 89; M. Bartosik-Purgat, Otoczenie kulturowe w biznesie, s. 181-182; L. Hawrysz, Konsekwencje różnic kulturowych, Studia i Materiały. Miscellanea Oeconomicae, 2009, 2, s. 251-252.

${ }^{52}$ E. Nowicka, S. Łodziński, U progu otwartego świata. Poczucie polskości i nastawienie Polaków wobec cudzoziemców w latach 1988-1998, Kraków 2001, s. 30.

${ }^{53}$ K. Kubin, J. Świerszcz, Wyzwania dla szkoty różnorodnej, s. 140.

${ }^{54}$ E. Nowicka, S. Łodziński, U progu otwartego świata, s. 31.

${ }_{55}$ J. Grzymała-Moszczyńska, za: A. Borkowska, Psychologiczne aspekty migracji w rozwoju dziecka, [w:] Dzieci z trudnościami adaptacyjnymi w młodszym wieku szkolnym. Aspekty rozwojowe i edukacyjne w kontekście specyfiki różnic kulturowych, red. E. Śmiechowska-Petrovskij, Warszawa 2016, s. 109. 
rozumieć „odmienność wzorów zachowań, systemów wartości i systemów symbolicznych, które decydują o sposobie postrzegania i wartościowania świata zewnętrznego oraz kształtowania zachowań przedstawicieli różnych kultur" 56 . Podobieństwo dwóch kultur na płaszczyźnie językowej, symbolicznej i aksjologicznej często pomaga zaaklimatyzować się w nowym środowisku. Z kolei, zderzenie kultur znacznie odmiennych okazuje się kontaktem wyjątkowo trudnym - „ludziom jednej kultury bardzo trudno przychodzi wyzbywanie się jej, przyjmowanie nowej, odmiennej"57. Im zatem bardziej kultura dzieci-imigrantów jest odmienna, tym mniejsze szanse na integrację w kraju pobytu i silniejsza podstawa do izolacji społecznej ${ }^{58}$.

Doświadczane problemy, w tym szczególnie różnice kulturowe mogłoby zniwelować, i tym samym zwiększyć prawdopodobieństwo integracji dzieci cudzoziemskich ze społecznością szkolną, zatrudnienie w placówce na stanowisku pomocy nauczyciela osoby pochodzącej z kraju rodzimego ucznia -imigranta lub władającej jego ojczystym językiem. Do jej obowiązków należałoby między innymi wspomaganie ucznia w czasie lekcji oraz w trudnych i konfliktowych sytuacjach, motywowanie go do nauki oraz wsparcie nauczycieli w kontaktach z rodzicami podopiecznego ${ }^{59}$. Niestety, i tu, podobnie jak w przypadku dodatkowych zajęć z języka polskiego, przeszkodą mogą się okazać kwestie finansowe. Organy prowadzące szkołę nie zawsze dysponują bowiem określoną kwotą pieniężną potrzebną na zatrudnienie pomocy nauczyciela dla dziecka z zagranicy, a przypadku większej grupy uczniów, pochodzących na dodatek z różnych krajów, kilku takich osób. Problemem może się także stać znalezienie kandydatów na to stanowisko, zwłaszcza w sytuacji, gdy uczniowie posługują się rzadkim językiem, na przykład uzbeckim czy mongolskim.

Barierę w integracji dzieci cudzoziemskich ze środowiskiem szkolnym stanowi także negatywny stosunek do nich klasowych kolegów i pozostałych uczniów, nauczycieli oraz rodziców polskich uczniów. Jak wspomniano wcześniej, integracja jest procesem dwustronnym, w którym odbywa się wzajemne oddziaływanie na siebie imigrantów i przedstawicieli grupy dominującej $^{60}$. W sytuacji braku akceptacji dzieci cudzoziemskich ze strony społeczności szkolnej, proces ich integracji nie zakończy się pomyślnie.

Uczniowie cudzoziemscy na skutek wcześniej opisanych trudności adaptacyjnych oraz nierzadko odmiennego wyglądu (np. innego koloru skóry),

${ }^{56}$ J. Hryniewicz, Imigracja i wielokulturowość w warunkach dużego dystansu kulturowego, Studia Regionalne i Lokalne, 2011, 3, s. 6.

${ }_{57}$ M. Janeta, Migranci a społeczność przyjmująca. Uwarunkowania strategii akulturacyjnych a kontakty ze społecznościa przyjmująca, Studia Migracyjne - Przegląd Polonijny, 2011, 2, s. 256.

58 D. Niedźwiedzki, Migracje i tożsamość. Od teorii do analizy przypadku, Kraków 2010, s. 100.

${ }^{59}$ B. Lachowicz, Uczniowie z różnych kultur w szkole, Warszawa 2017, s. 11.

${ }^{60}$ A. Grzymała-Kozłowska, „Integracja” - próba rekonstrukcji pojęcia, s. 35. 
często są napiętnowani i wyśmiewani przez swoich rówieśników. Dzieci te stają się obiektem drwin i żartów, głównie z powodu nieznajomości języka polskiego ${ }^{61}$. Poniższa wypowiedź imigranta pochodzenia syryjskiego, który przyjechał do Polski będąc w wieku szkolnym, może stanowić tego ilustrację:

Pamiętam, jak pani z historii po 3 miesiacach pobytu mojego w tej szkole mnie zapytała. To było zdecydowanie za wcześnie, ale ja byłem przygotowany, nauczyłem się tych dat. Zadała mi dwa pytania, na które odpowiedziałem, potem kolejne i już totalnie sie pogubiłem, bo nie rozumiałem o co pyta. Patrzyłem się więc na klasę błagalnym wzrokiem, aby mi pomogli. I pomogli - powiedzieli co mam odpowiedzieć. Tyle tylko, że to nie była prawidłowa odpowiedź, ale pewne słowo, które oznaczało, mówiąc delikatnie: zamknij się w najgorszym pojęciu. Ale ja myślałem, że to jest odpowiedź. I to powtórzyłem. Pani spaliła się ze wstydu, a klasa cała się śmiała.

Przyczynę niewłaściwych zachowań polskich uczniów w stosunku do kolegów z zagranicy może stanowić nieprzygotowanie ich przez nauczycieli na obecność w klasie obcojęzycznego dziecka oraz panujące powszechnie stereotypy, które zawierają wiedzę powierzchowną, na podstawie której dokonuje się generalizacji, oceny zjawisk, ludzi bez posiadania wystarczających do tego informacji ${ }^{62}$. Konsekwencją tego jest "przypisywanie cudzoziemcom niepożądanych cech i spychanie na niższe pozycje w społeczeństwie" 63 . Agresję słowną i fizyczną wobec uczniów-imigrantów może również wzmagać brak prowadzenia ze strony szkoły działań zapobiegających stereotypowemu myśleniu, uprzedzeniom i dyskryminacji. Warto nadmienić, że różne formy nieprzychylności ze strony polskich uczniów mogą wyzwalać u dzieci odmiennych kulturowo spontaniczne, nieadekwatne, agresywne reakcje obronne ${ }^{64}$.

Trudnością w procesie integracji uczniów cudzoziemskich ze środowiskiem szkolnym jest także brak wsparcia i pomocy ze strony nauczycieli, który może wynikać z niechęci edukatorów do dzieci z zagranicy lub po prostu z braku ich odpowiedniego przygotowania do pracy z nimi. Badania prowadzone przez Barbarę Dobrowolską wśród nauczycieli prowadzących zajęcia z dziećmi cudzoziemskimi pokazały, że poziom ich umiejętności międzykulturowych ${ }^{65}$, czyli zdolności postrzegania różnicy kulturowej, budowania

61 A. Kosowicz, Dziecko cudzoziemskie w polskim systemie edukacyjnym. Edukacja międzykulturowa w wymiarze praktycznym, [w:] Edukacja międzykulturowa w Polsce, s. 153.

62 K. Struś, J. Więckowska, O stereotypach etnicznych. Czy są konieczne, pomagają czy przeszkadzają w funkcjonowaniu w obcej kulturze? [w:] Swojskość i obcość. O akulturacji imigrantów w Polsce, red. H. Malewska-Peyre, Warszawa 2001, s. 71.

${ }^{63}$ J. Szkudlarek, E. Garbicz, Cudzoziemcy w Polsce - swoi czy obcy? Studium przypadku na podstawie Wietnamczyków, [w:] Społeczeństwo wobec Innego, s. 227.

${ }^{64}$ K. Kubin, J. Świerszcz, Wyzwania dla szkoty różnorodnej, s. 138.

65 B. Dobrowolska, Kompetencje nauczycieli a wielokulturowość w świetle badań własnych, Studia Pedagogiczne. Problemy Społeczne, Edukacyjne i Artystyczne, 2012, 21, s. 21-22. 
dystansu, otwartości w sytuacjach komunikacji z jednostkami pochodzącymi $\mathrm{z}$ odmiennych kultur ${ }^{66}$ jest niski. Wielu nauczycieli ma problem ze zrozumieniem nietypowych zachowań uczniów cudzoziemskich, które ostatecznie odczytują i oceniają przez pryzmat zinternalizowanych wartości kultury polskiej. W efekcie, postępowanie dzieci cudzoziemskich wybiegające poza dopuszczalne ramy zachowań przeciętnego polskiego ucznia traktowane jest jako niegrzeczność, nieposłuszeństwo i powoduje uruchomianie standardowych działań w stosunku do dzieci sprawiających trudności wychowawcze $^{67}$. Część nauczycieli przejawia ponadto postawy, które opierają się na intencji zintegrowania dzieci-imigrantów z polskimi rówieśnikami, poprzez narzucanie im polskich wzorców dotyczących zainteresowań literackich czy upodobań kulturalnych oraz zachęcanie do utożsamiania się z polskim dziedzictwem narodowym ${ }^{68}$. Tymczasem, jak podkreślono wcześniej, dla skutecznego procesu integracji dzieci cudzoziemskich istotne jest uwzględnienie przez członków społeczeństwa przyjmującego poszanowania prawa do zachowania własnej odrębności kulturowej przez imigrantów.

Również opiekunowie polskich uczniów bywają sceptycznie nastawieni do uczenia się w klasie ich dzieci osób odmiennych kulturowo ${ }^{69}$, co może wynikać z ogólnej niechęci polskiego społeczeństwa do osiedlania się w naszym kraju cudzoziemców, zwłaszcza pochodzących z krajów oddalonych od nas kulturowo. Potwierdzają to między innymi badania zatytułowane "Stosunek Polaków i Czechów do przyjmowania uchodźców" (s. 1-7), zrealizowane przez Centrum Badań Opinii Społecznych (CBOS) w lipcu 2018 roku. Wynika z nich, że ponad połowa badanych Polaków $(60 \%)$ jest przeciwna zamieszkaniu u nas uchodźców. Prawie co trzeci respondent (29\%) twierdzi, że uchodźcom powinno się świadczyć pomoc, ale tylko do czasu, kiedy będą mogli bezpiecznie powrócić do swojej ojczyzny. Jedynie 5\% badanych Polaków uważa, że Polska powinna udzielać schronienia osobom prześladowanym w swoich krajach. $6 \%$ badanych nie ma zdania w tej kwestii. Stosunek do przyjmowania uchodźców nie zmienił się znacznie na przestrzeni ostatnich lat. Większą przychylność do pobytu uchodźców w Polsce przez ograniczony czas deklarują mieszkańcy większych miast oraz osoby z wyższym wykształceniem. Prawie $3 / 4$ badanych $(72 \%)$ jest zdecydowanie przeciwna przyjmowaniu uchodźców z Bliskiego Wschodu i Afryki, z czego 46\% osób wyraża zdecydowaną niechęć wobec relokacji uchodźców spoza Europy. Tylko 22\% respon-

${ }^{66}$ E. Chromiec, Mniejszości narodowe i etniczne w Polsce, s. 223.

${ }^{67}$ K. Kubin, J. Świerszcz, Wyzwania dla szkoty różnorodnej, s. 132.

${ }^{68}$ D. Szelewa, Integracja a polityka edukacyjna, Warszawa 2010, s. 33.

69 B. Chisi i in., Dziecko migranckie w naszej szkole. Rekomendacje nauczycieli dla nauczycieli, file:/ / C:/Users/PEDAGO 1/AppData/Local/Temp/dziecko_migranckie_w_naszej_klasie. pdf [dostęp: 10.04.2019]. 
dentów zalicza się do zwolenników otrzymania przez migrantów spoza UE statusu uchodźcy w naszym kraju. Zupełnie inaczej przedstawia się stosunek Polaków do udzielenia ochrony Ukraińcom z terenów objętych konfliktem zbrojnym. Ponad połowa badanych (56\%) popiera przyjęcie uchodźców z sąsiedniego kraju, a nieco ponad jedna trzecia $(35 \%)$ wyraża sprzeciw ${ }^{70}$.

Omawiając stosunek Polaków do imigrantów przebywających w Polsce, warto również wspomnieć o badaniach Helsińskiej Fundacji Praw Człowieka, zatytułowanych „Rasizm w Polsce. Raport z badań wśród osób, które doświadczyły przemocy ze względu na swoje pochodzenie etniczne, rasowe lub narodowe", zrealizowanych w 2010 roku. Wynika z nich, że wobec mieszkających w Polsce cudzoziemców przejawiane są postawy rasistowskie. Najczęściej spotykane oznaki rasizmu w Polsce to publiczne znieważanie i wyzywanie ze względu na pochodzenie. Takiej agresji słownej doświadczają głównie osoby o ciemnym kolorze skóry. Prawie wszyscy migranci pochodzących z krajów afrykańskich słyszą pod swoim adresem słowa: „małpa”, ,"czarna małpa”, ,, asfalt", "bambo", "goryl”. Do cudzoziemców często kierowane są komentarze, że Polska nie jest ich domem, w związku z czym powinni wracać do swoich ojczyzn. Słowom tym nierzadko towarzyszy agresja fizyczna - pobicia, uderzenia, pchnięcia. Do ataków dochodzi zazwyczaj w miejscach publicznych, często w obecności innych osób - w środkach transportu publicznego lub na przystankach, na ulicy, podczas spacerów lub imprez masowych ${ }^{71}$.

Poczucie braku akceptacji ze strony ludności rodzimej, jakiego doświadczają dzieci odmienne kulturowo staje się na ogół źródłem niskiego poczucia własnej wartości, gorszej kondycji psychicznej², a także często prowadzi do autostygmatyzacji, czyli utożsamiania się jednostki ze społecznie narzuconym jej piętnem ${ }^{73}$.

\section{Dzieci uchodźcze w polskiej szkole}

Szczególnych trudności w integracji ze środowiskiem szkolnym doświadczają dzieci uchodźcze, a więc nieletni, którzy wraz ze swoimi opiekunami uciekli przed prześladowaniem w swojej ojczyźnie, z powodu rasy, religii, narodowości, przekonań politycznych lub przynależności do określonej gru-

${ }^{70}$ Stosunek Polaków i Czechów do przyjmowania uchodźców, Warszawa 2018, s. 1-7.

71 A. Mikulska, Rasizm w Polsce. Raport z badań wśród osób, które doświadczyły przemocy ze względu na swoje pochodzenie etniczne, rasowe lub narodowe, Warszawa 2010, s. 41-45.

72 A. Nowakowska, Wptyw migracji zarobkowej, s. 79.

${ }^{73}$ E. Wysocka, "My" i "oni" - dlaczego tak trudno być razem? Odpowiedź pedagoga, psychologa i socjologa, [w:] Migracja, uchodźctwo, wielokulturowość. Zderzenie kultur we wspótczesnym świecie, red. D. Lalak, Warszawa 2007, s. 34. 
py społecznej ${ }^{74}$. Ich problemy spowodowane są głównie dramatycznymi okolicznościami towarzyszącymi migracji do Polski. Nierzadko bowiem przed $\mathrm{i} \mathrm{w}$ trakcie przemieszczeń przeżyły wojnę, utratę bliskich, długie pobyty w obozach dla uchodźców i tym podobne ${ }^{75}$. Duża część z nich w wyniku doświadczonych zdarzeń cierpi na zespół stresu pourazowego (PTSD), cechujący się: odtwarzaniem traumatycznych wydarzeń (np. wojny) na jeden lub więcej sposobów, na przykład poprzez uporczywe wspomnienia, powracające koszmary senne, silne reakcje lękowe na bodźce skojarzone z wydarzeniami; utrzymującym się unikaniem bodźców kojarzących się z traumą; zmniejszeniem ogólnej reaktywności; poczuciem wyobcowania, pesymistyczną oceną przyszłości; utrzymywaniem się zwiększonego pobudzenia w postaci trudności ze snem, wybuchów gniewu, trudności z koncentracją; poczuciem silnego dystresu i upośledzeniem różnych obszarów funkcjonowania społecznego lub zawodowego ${ }^{76}$. Dla dzieci uchodźców charakterystyczne jest także doznawanie żałoby kulturowej, wywołanej utratą ważnych dla nich osób i/lub rzeczy ${ }^{77}$.

Scharakteryzowane przeżycia nie pozostają bez wpływu na funkcjonowanie psychofizyczne dzieci uchodźczych w szkole. Uczniowie ci mają duże trudności ze skupieniem się na omawianych treściach, przez co doświadczają niepowodzeń dydaktycznych. Cechuje ich także niechęć do nauki języka polskiego, co zmniejsza szansę na integrację ze społecznością szkolną ${ }^{78}$. Warto również nadmienić, że znaczna część dzieci uchodźców w ogóle nie uczęszcza na zajęcia szkolne. Dowodem tego mogą być dane Wysokiego Komisarza Narodów Zjednoczonych do spraw Uchodźców (UNHCR), z których wynika, że ponad połowa dzieci uchodźców w Polsce nie realizuje obowiązku szkolnego, a wśród tych, które pojawiają się w szkole, połowa nie przystępuje do egzaminów z języka polskiego. Na ogół karierę szkolną przeciętnego ucznia uchodźczego wyróżnia stosunkowo krótki okres kształcenia oraz przedwczesne zakończenie edukacji ${ }^{79}$. Doświadczane niepowodzenia dydaktyczne oraz nierealizowanie obowiązku szkolnego mogą także wynikać z, oprócz wcześniej wspomnianych traum, poczucia tymczasowości, charak-

${ }^{74}$ Ustawa z 13 czerwca 2003 r. o udzielaniu cudzoziemcom ochrony na terytorium Rzeczypospolitej Polskiej, art. 13.

${ }^{75}$ M. Kristiansen, A. Mygind, A. Krasnik, Health effects of migration, Danisch Medical Bulletin, 2007, 54, s. 46.

${ }^{76}$ A. Lipczyński, Psychologiczna interwencja w sytuacjach kryzysowych, Warszawa 2007, s. 37.

${ }_{77}$ M. Piegat-Kaczmarzyk, Z. Rejmer, Psychologiczne skutki uchodźstwa, file:///C:/Users/ Pedagog\%20Gimnazjum/Desktop/część\%201_Uchodźcy\%20i\%20cudzoziemcy\%20w\%20Polsce.pdf [dostęp: 03.04.2019], s. 32-34.

${ }^{78}$ K. Białek, Międzykulturowość w szkole, s. 14.

${ }^{79} \mathrm{~K}$. Błeszyńska, Dzieci obcokrajowców w polskich placówkach oświatowych - perspektywa szkoty. Raport z badań, Warszawa 2010, s. 12-13. 
terystycznego dla większości uchodźców, w tym także ich dzieci. Związane jest ono z brakiem wiedzy na temat długości pobytu w kraju przyjmującym. Czas oczekiwania na status uchodźcy w Polsce $\mathrm{z}$ reguły trwa około sześciu miesięcy. Dzieci uchodźcze muszą zatem przez pół roku oczekiwać na decyzję o swoim dalszym losie: czy będą mogły pozostać w Polsce czy też powrócą do swojej ojczyzny lub wyemigrują do innego kraju. Ten stan niepewności dla większości z nich jest bardzo dotkliwy i wpływa negatywnie na ich poczucie bezpieczeństwa oraz motywację do nauki. Dzieci te nie wiedzą, czego mogą się spodziewać w najbliższych dniach, boją się także podejmować trud uczenia się, ponieważ może się okazać za kilka miesięcy, że wraz z rodziną muszą opuścić Polskę, a to będzie oznaczać, że czas poświęcony na przykład na rozwijanie umiejętności komunikowania się w języku polskim okaże się stracony ${ }^{80}$.

\section{Podsumowanie}

Reasumując, integracja uczniów cudzoziemskich ze środowiskiem szkolnym jest bardzo ważnym procesem. Niestety, dzieci odmienne kulturowo na drodze do niej napotykają wiele barier, które znacząco utrudniają pomyślny jej przebieg. Należy do nich przede wszystkim: nieznajomość języka polskiego i zasad rządzących komunikacją niewerbalną i relacyjną w Polsce, różnice kulturowe, doświadczane problemy emocjonalne, różnice w systemie edukacji, brak otrzymywania adekwatnej pomocy językowej oraz wsparcia ze strony osoby władającej językiem kraju pochodzenia uczniów cudzoziemskich, negatywny stosunek rówieśników, kadry pedagogicznej i rodziców polskich do osób z zagranicy.

W związku z tym bardzo ważne są działania, które mogłyby pomóc dzieciom-imigrantom $\mathrm{w}$ procesie integracji. Czynności te powinny być skierowane bezpośrednio do uczniów cudzoziemskich, jak również do społeczności szkolnej, ponieważ, jak zostało nadmienione wyżej, od jej postawy zależą efekty integracji dzieci z doświadczeniem migracyjnym. W przypadku pracy z uczniami cudzoziemskimi istotne jest przede wszystkim zapewnienie im jak największej liczby godzin dodatkowych zajęć z języka polskiego, prowadzonych przez wykwalifikowane osoby oraz udziału w zajęciach rozwijających ich kompetencje międzykulturowe, co znacząco zintensyfikuje szansę na skuteczne i bezkonfliktowe porozumiewanie się z Polakami. Bardzo ważne jest również wsparcie ze strony psychologa, włączanie dzieci-imigrantów do życia klasowego tak, by zapobiec ich izolacji i wykluczeniu oraz przeciwdzia-

${ }^{80}$ A. Kosowicz, Dziecko cudzoziemskie w polskim systemie edukacyjnym, s. 153. 
łanie wszelkiej dyskryminacji w środowisku szkolnym. Nauczyciele powinni także przygotować polskich uczniów na dołączenie do ich klasy dziecka odmiennego kulturowo oraz ich rodziców, ponieważ postawy dzieci wobec uczniów cudzoziemskich z reguły są odzwierciedleniem stosunku ich rodziców do obcokrajowców. Bardzo istotne jest również doskonalenie przez nauczycieli swojego warsztatu pracy w środowisku zróżnicowanym kulturowo. W wielu dokumentach Unii Europejskiej, na przykład zatytułowanym „Wspólne europejskie zasady dotyczące kompetencji i kwalifikacji nauczycieli", możemy odnaleźć zapis mówiący o tym, że współcześni edukatorzy powinni posiadać umiejętność pracy w wielokulturowej i zróżnicowanej społecznie klasie ${ }^{81}$. Szczególnie cenna jest zdolność dostrzegania specyficznych problemów i potrzeb uczniów obcojęzycznych, świadomość wynikających z nich zadań oraz chęć ich podejmowania ${ }^{82}$.

\section{BIBLIOGRAFIA}

Bartosik-Purgat M., Otoczenie kulturowe w biznesie międzynarodowym, Polskie Wydawnictwo Ekonomiczne, Warszawa 2006.

Bera R., Aksjologiczny sens pracy a poczucie jakości życia młodych emigrantów polskich, Wydawnictwo Uniwersytetu Marii Curie-Skłodowskiej, Lublin 2008.

Bernacka-Langier A., Brzezicka E., Doroszuk S. i in., Ku wielokulturowej szkole w Polsce. Pakiet edukacyjny z programem nauczania jezzyka polskiego jako drugiego dla I, II i III etapu kształcenia, Warszawskie Centrum Innowacji Edukacyjno-Społecznych i Szkoleń, Warszawa 2010.

Berry J., Akulturacja: harmonijne życie pośród dwóch kultur, przekł. A. Mleczko, Rocznik Pedagogiczny, 2006, 29.

Białek K., Międzykulturowość w szkole. Poradnik dla nauczycieli i specjalistów, Ośrodek Rozwoju Edukacji, Warszawa 2015.

Błeszyńska K., Dzieci obcokrajowców w polskich placówkach oświatowych - perspektywa szkoty. Raport z badań, Ośrodek Rozwoju Edukacji, Warszawa 2010.

Bolten J., Interkulturowa kompetencja, Wydawnictwo Naukowe UAM, Poznań 2006.

Borkowska A., Psychologiczne aspekty migracji w rozwoju dziecka, [w:] Dzieci z trudnościami adaptacyjnymi w młodszym wieku szkolnym. Aspekty rozwojowe i edukacyjne w kontekście specyfiki różnic kulturowych, red. E. Śmiechowska-Petrovskij, Wydawnictwo Naukowe UKSW, Warszawa 2016.

Brzozowska A., Wybrane grupy i charakterystyki imigracji do Polski, http://www.tea.org.pl/ userfiles/file/Seminaria/wybrane_grupy_i_charakterystyki_imigracji_do_polski_-_ tekst_autorstwa_mgr_anity_brzozowskiej.pdf [dostęp: 28.11.2015].

${ }^{81}$ Common European Principles for Teacher Competences and Qualifications, European Comission, Directorate-General for Education and Culture, za: A. Bernacka-Langier, E. Brzezicka, S. Doroszuk i in., Ku wielokulturowej szkole w Polsce. Pakiet edukacyjny z programem nauczania jezzyka polskiego jako drugiego dla I, II i III etapu ksztatcenia, Warszawa 2010, s. 11.

${ }^{82}$ K. Błeszyńska, Dzieci obcokrajowców w polskich placówkach oświatowych, s. 10. 
Budyta-Budzyńska M., Adaptacja, integracja, asymilacja - próba ujęcia teoretycznego, [w:] Integracja czy asymilacja? Polscy imigranci na Islandii, red. M. Budyta-Budzyńska, Wydawnictwo Naukowe Scholar, Warszawa 2011.

Chisi B., Jach I., Pansiuk T., Pawlic-Rafałowska E., Yeremyan-Woźniakowska M., Dziecko migranckie w naszej szkole. Rekomendacje nauczycieli dla nauczycieli, file:/ / C:/Users/ PEDAGO 1/AppData/Local/Temp/dziecko_migranckie_w_naszej_klasie.pdf [dostęp: 10.04.2019].

Chromiec E., Mniejszości narodowe i etniczne w Polsce - pytania i problemy okresu transformacji, [w:] Społeczeństwo wobec Innego. Kategoria Innego w naukach społecznych $i \dot{z y c i u}$ publicznym, red. L. Dziewięcka-Bokun, A. Śledzińska-Simon, Wydawnictwo Adam Marszałek, Torun 2010.

Chutnik M., Szok kulturowy. Przyczyny, konsekwencje, przeciwdziałanie, Wydawnictwo Universitas, Kraków 2007.

Dobrowolska B., Kompetencje nauczycieli a wielokulturowość w świetle badań własnych, Studia Pedagogiczne. Problemy Społeczne, Edukacyjne i Artystyczne, 2012, 21.

Fihel A., Koszt edukacji cudzoziemskich dzieci, Biuletyn Migracyjny, 2014, 49.

Gocalski W., Migracje, [w:] Barwy i cienie migracji, red. W. Gocalski, Wojskowa Akademia Techniczna, Warszawa 2009.

Górny A., Kaczmarczyk P., Napierała J., Toruńczyk-Ruiz S., Raport z badania imigrantów w Polsce, Ośrodek Badań nad Migracjami Fundacja, Warszawa 2013.

Grzymała-Kozłowska A., "Integracja” - próba rekonstrukcji pojęcia, [w:] Problemy integracji imigrantów. Koncepcje, badania, polityki, red. A. Grzymała-Kozłowska, S. Łodziński, Wydawnictwo Uniwersytetu Warszawskiego, Warszawa 2008.

Grzymała-Kozłowska A., Łodziński S. (red.), Problemy integracji imigrantów. Koncepcje, badania, polityki, Wydawnictwo Uniwersytetu Warszawskiego, Warszawa 2008.

Grzymała-Moszczyńska H., Uchodźcy jako wyzwanie dla polskiego systemu opieki zdrowotnej, [w:] Migranci na polskim rynku pracy. Rzeczywistość, problemy, wyzwania, red. W. Klaus, Stowarzyszenie Interwencji Prawnej, Warszawa 2007.

Grzymała-Moszczyńska J., Psychologiczne aspekty powrotów z emigracji - przegląd teoretyczny, Studia Migracyjne - Przegląd Polonijny, 2014, 4.

Hawrysz L., Konsekwencje różnic kulturowych, Studia i Materiały. Miscellanea Oeconomicae, $2009,2$.

Hryniewicz J., Imigracja i wielokulturowość w warunkach dużego dystansu kulturowego, Studia Regionalne i Lokalne, 2011, 3.

https:/ / udsc.gov.pl/ podsumowanie-legalizacja-pobytu-w-2018-r/ [dostęp: 02.04.2019r.].

Iglicka K., Rola polityki migracyjnej Polski w kształtowaniu migracji z Ukrainy z perspektywy teorii systemów, [w:] Migracje kobiet. Perspektywa wielowymiarowa, red. K. Slany, Wydawnictwo Uniwersytetu Jagiellońskiego, Kraków 2008.

Janeta M., Migranci a spoteczność przyjmująca. Uwarunkowania strategii akulturacyjnych a kontakty ze społecznościa przyjmująca, Studia Migracyjne - Przegląd Polonijny, 2011, 2.

Kaźmierkiewicz P., Uwarunkowania integracji cudzoziemców w Polsce, [w:] Integracja cudzoziemców w Polsce. Wybrane aspekty, red. M. Bieniecki, P. Kaźmierkiewicz, B. Smoter, Instytut Spraw Publicznych, Warszawa 2006.

Kicinger A., Unia Europejska wobec zagadnienia integracji imigrantów, CEFMR Working Paper, 2005, 2.

Konstytucja Rzeczypospolitej Polskiej z 2 kwietnia 1997 r. (DzU 1997, nr 78, poz. 483).

Kownacka E., Od szoku do adaptacji: psychologiczne konsekwencje wyjazdu za granice, [w:] Doradztwo zawodowe a wyzwania międzykulturowe, red. D. Cieślikowska, E. Kownacka, 
E. Olczak, A. Paszkowska-Rogacz, Krajowy Ośrodek Wspierania Edukacji Zawodowej i Ustawicznej, Warszawa 2006.

Kosowicz A., Dziecko cudzoziemskie w polskim systemie edukacyjnym. Edukacja międzykulturowa w wymiarze praktycznym, [w:] Edukacja międzykulturowa w Polsce wobec nowych wyzwań, red. A. Paszko, Stowarzyszenie Willa Decjusza, Kraków 2011.

Kristiansen M., Mygind A., Krasnik A., Health effects of migration, Danisch Medical Bulletin, 2007,54 .

Kubin K., Świerszcz J., Wyzwania dla szkoły różnorodnej. Wstępna analiza mechanizmów wykluczania dzieci i rodzin migranckich w strukturach szkoty w Polsce, [w:] Edukacja międzykulturowa w Polsce wobec nowych wyzwan, red. A. Paszko, Stowarzyszenie Willa Decjusza, Kraków 2011.

Lachowicz B., Uczniowie z różnych kultur w szkole, Ośrodek Rozwoju Edukacji, Warszawa 2017.

Lipczyński A., Psychologiczna interwencja w sytuacjach kryzysowych, Wydawnictwo Difin, Warszawa 2007.

Łodziński S., Grzymała-Kazłowska A., Koncepcje, badania i praktyki integracji imigrantów. Doświadczenia polskie w europejskim kontekście, Studia Migracyjne - Przegląd Polonijny, 2011, 2.

Mikulska A., Rasizm w Polsce. Raport z badań wśród osób, które doświadczyły przemocy ze względu na swoje pochodzenie etniczne, rasowe lub narodowe, Helsińska Fundacja Praw Człowieka, Warszawa 2010.

Narodowy Spis Powszechny Ludności i Mieszkań 2011, Główny Urząd Statystyczny, Warszawa 2011.

Niedźwiedzki D., Migracje i tożsamość. Od teorii do analizy przypadku, Zakład Wydawniczy Nomos, Kraków 2010.

Nowakowska A., Wptyw migracji zarobkowej na jakość życia rodzinnego, [w:] Psychologia rodziny. Matżeństwo i rodzina wobec wspótczesnych wyzwań, red. T. Rostowska, Wydawnictwo Difin, Warszawa 2009.

Nowicka E., Łodziński S., U progu otwartego świata. Poczucie polskości i nastawienie Polaków wobec cudzoziemców w latach 1988-1998, Zakład Wydawniczy Nomos, Kraków 2001.

Olczak E., Różnice kulturowe w funkcjonowaniu człowieka, [w:] Doradztwo zawodowe a wyzwania międzykulturowe, red. D. Cieślikowska, E. Kownacka, E. Olczak, A. Paszkowska-Rogacz, Krajowy Ośrodek Wspierania Edukacji Zawodowej i Ustawicznej, Warszawa 2006.

Piegat-Kaczmarzyk M., Rejmer Z., Psychologiczne skutki uchodźstwa, file:///C:/Users/ Pedagog\%20Gimnazjum/Desktop/część\%201_Uchodźcy\%20i\%20cudzoziemcy\%20 w\%20Polsce.pdf [dostęp: 03.04.2019].

Rocznik Statystyczny Rzeczpospolitej Polskiej, Główny Urząd Statystyczny, Warszawa 2017.

Rozporządzenie Ministra Edukacji Narodowej z 23 sierpnia 2017 r. w sprawie kształcenia osób niebędących obywatelami polskimi oraz osób będących obywatelami polskimi, które pobierały naukę $\mathrm{w}$ szkołach funkcjonujących $\mathrm{w}$ systemach oświaty innych państw (DzU 2017, poz. 1655).

Sikorski W., Różnice międzykulturowe w zachowaniach i komunikacji niewerbalnej, [w:] Wieloaspektowość komunikacji społecznej w środowisku wielu kultur, red. K. Czerwiński, M. Fiedor, D. Wosik-Kawala, Gnieźnieńska Szkoła Wyższa Millenium, Wydawnictwo Adam Marszałek, Torun 2012.

Stosunek Polaków i Czechów do przyjmowania uchodźców, CBOS, Warszawa 2018.

Struś K., Więckowska J., O stereotypach etnicznych. Czy sa konieczne, pomagaja czy przeszkadzaja w funkcjonowaniu w obcej kulturze? [w:] Swojskość i obcość. O akulturacji imigrantów 
w Polsce, red. H. Malewska-Peyre, Wydawnictwo Instytutu Psychologii PAN, Warszawa 2001.

Szelewa D., Integracja a polityka edukacyjna, Raporty i Analizy, Seria „Integracja”, Centrum Stosunków Międzynarodowych, Warszawa 2010.

Szkudlarek J., Garbicz E., Cudzoziemcy w Polsce - swoi czy obcy? Studium przypadku na podstawie Wietnamczyków, [w:] Społeczeństwo wobec Innego. Kategoria Innego w naukach społecznych i życiu publicznym, red. L. Dziewięcka-Bokun, A. Śledzińska-Simon, Wydawnictwo Adam Marszałek, Torun 2010.

Szopski M., Komunikowanie międzykulturowe, Wydawnictwa Szkolne i Pedagogiczne, Warszawa 2005.

Włodarczak K., Proces adaptacji wspótczesnych emigrantów polskich do życia w Australii, Prace Migracyjne, 2005, 3.

Ustawa z 13 czerwca 2003 r. o udzielaniu cudzoziemcom ochrony na terytorium Rzeczypospolitej Polskiej (DzU 2003, nr 128, poz. 1176).

Ustawa z 14 grudnia 2016 r. Prawo oświatowe (DzU z 2018, poz. 996, 1000, 1290, 1669 i 2245 oraz DzU z 2019, poz. 534).

World Migration Report 2018, https://www.iom.int/wmr/world-migration-report-2018 [dostęp: 10/04/2019].

Wysocka E., "My" i „oni” - dlaczego tak trudno być razem? Odpowiedź pedagoga, psychologa i socjologa, [w:] Migracja, uchodźctwo, wielokulturowość. Zderzenie kultur we wspótczesnym świecie, red. D. Lalak, Wydawnictwo Akademickie Żak, Warszawa 2007.

Wysocka E., Akulturacja, [w:] Encyklopedia pedagogiczna XXI wieku, red. T. Pilch, Wydawnictwo Akademickie Żak, Warszawa 2003.

Zestawienie liczbowe dotyczace postępowań prowadzonych wobec cudzoziemców w 2018 roku, Urząd ds. Cudzoziemców, Warszawa 2018, https://udsc.gov.pl/statystyki/raporty -okresowe/zestawienia-roczne/ [pobrano: 02.04.2019]. 